\title{
A combination of cytokines EGF and CNTF protects the functional beta cell mass in mice with short-term hyperglycaemia
}

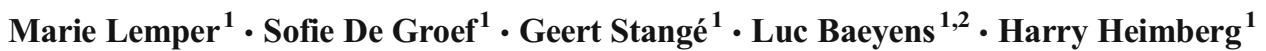

Received: 11 March 2016 / Accepted: 24 May 2016 / Published online: 18 June 2016

(C) Springer-Verlag Berlin Heidelberg 2016

\begin{abstract}
Aims/hypothesis When the beta cell mass or function declines beyond a critical point, hyperglycaemia arises. Little is known about the potential pathways involved in beta cell rescue. As two cytokines, epidermal growth factor (EGF) and ciliary neurotrophic factor (CNTF), restored a functional beta cell mass in mice with long-term hyperglycaemia by reprogramming acinar cells that transiently expressed neurogenin 3 (NGN3), the current study assesses the effect of these cytokines on the functional beta cell mass after an acute chemical toxic insult. Methods Glycaemia and insulin levels, pro-endocrine gene expression and beta cell origin, as well as the role of signal transducer and activator of transcription 3 (STAT3) signalling, were assessed in $\mathrm{EGF}+\mathrm{CNTF}$-treated mice following acute hyperglycaemia.

Results The mice were hyperglycaemic 1 day following i.v. injection of the beta cell toxin alloxan, when the two cytokines were applied. One week later, $68.6 \pm 4.6 \%$ of the mice had responded to the cytokine treatment and increased their
\end{abstract}

Luc Baeyens and Harry Heimberg are joint senior authors of this study.

Electronic supplementary material The online version of this article (doi:10.1007/s00125-016-4023-3) contains peer-reviewed but unedited supplementary material, which is available to authorised users.

Luc Baeyens

lbaeyens@diabetes.ucsf.edu

Harry Heimberg

Harry.Heimberg@vub.ac.be

1 Diabetes Research Center, Vrije Universiteit Brussel, Laarbeeklaan 103, 1090 Brussels, Belgium

2 Diabetes Center, Eli and Edythe Broad Center for Regenerative Medicine and Stem Cell Research, University of California San Francisco, San Francisco, CA 94143-0669, USA

insulin $^{+}$cell number to $30 \%$ that of normoglycaemic control mice, resulting in restoration of euglycaemia. Although insu$\operatorname{lin}^{-} \mathrm{NGN}^{+}$cells appeared following acute EGF+CNTF treatment, genetic lineage tracing showed that the majority of the insulin $^{+}$cells originated from pre-existing beta cells. Beta cell rescue by $\mathrm{EGF}+\mathrm{CNTF}$ depends on glycaemia rather than on STAT3-induced NGN3 expression in acinar cells.

Conclusions/interpretation In adult mice, EGF+CNTF allows the rescue of beta cells in distress when treatment is given shortly after the diabetogenic insult. The rescued beta cells restore a functional beta cell mass able to control normal blood glucose levels. These findings may provide new insights into compensatory pathways activated early after beta cell loss.

Keywords Acinarcell $\cdot$ Betacell $\cdot$ Cell protection $\cdot$ Cytokine $\cdot$ Hyperglycaemia $\cdot$ Neurogenin $3 \cdot$ Transdifferentiation

\begin{tabular}{|c|c|}
\hline \multicolumn{2}{|c|}{ Abbreviations } \\
\hline ALX & Alloxan \\
\hline $\mathrm{ALX}_{1 \mathrm{~d} / \mathrm{CK}}$ & $\begin{array}{l}\text { Mice injected with ALX followed } 1 \text { day } \\
\text { later, by treatment with cytokines EGF } \\
\text { and CNTF }\end{array}$ \\
\hline $\mathrm{ALX}_{1 \mathrm{~d} / \mathrm{CTR}}$ & $\begin{array}{l}\text { Mice injected with ALX followed } 1 \text { day } \\
\text { later, by treatment with vehicle }\end{array}$ \\
\hline AMY & Amylase \\
\hline CNTF & Ciliary neurotrophic factor \\
\hline CK & Cytokine \\
\hline EG & $\mathrm{EGF}+$ gastrin \\
\hline EGF & Epidermal growth factor \\
\hline GFP & Green fluorescent protein \\
\hline NG & Normoglycaemic \\
\hline $\mathrm{NG}_{1 \mathrm{~d} / \mathrm{CK}}$ & $\begin{array}{l}\text { Mice injected with vehicle followed } 1 \text { day } \\
\text { later, by treatment with cytokines EGF } \\
\text { and CNTF }\end{array}$ \\
\hline
\end{tabular}

Abbreviations

Alloxan later, by treatment with cytokines EGF 


$\begin{array}{ll}\text { NG }_{1 \mathrm{~d} / \mathrm{CTR}} & \begin{array}{l}\text { Mice injected with vehicle followed } 1 \text { day } \\ \text { later, by treatment with vehicle }\end{array} \\ \text { NGN3 } & \text { Neurogenin 3 } \\ \text { PDX1 } & \begin{array}{l}\text { Pancreatic and duodenal homebox 1 } \\ \text { Signal transducer and activator of }\end{array} \\ \text { STAT3 } & \begin{array}{l}\text { transcription 3 } \\ \text { Tamoxifen }\end{array} \\ \text { TAM } & \text { Yellow fluorescent protein }\end{array}$

\section{Introduction}

Loss of beta cell mass and function result in chronically elevated glycaemia that may result in diabetes. Reinstating a functional beta cell mass that is capable of monitoring normal blood sugar level may serve as effective disease treatment. The nature of cells within the adult pancreas able to give rise to new beta cells is the subject of debate.

Genetic lineage tracing in mice demonstrates that, under conditions of normal physiology or modest beta cell damage, pre-existing beta cells are responsible for turnover and compensatory growth $[1,2]$. In addition, dedifferentiation of beta cells is also identified as an important mechanism for beta cell failure in studies on beta cell survival and mass, both in vitro [3] and in vivo [4]. However, the extent of the tissue insult appears to be a determining factor in the origin of new beta cells. In an experimental setup, facultative progenitor cells can be activated as an in vivo source of new beta cells in the adult pancreas following extensive tissue damage [5]. Although these cells seemed to originate from cells located along the lining of the exocrine ducts, a duct origin was contradicted by genetic lineage tracing with different duct-specific promoters [6-10].

In adult mice, alpha cells can be an alternative source of new beta cells as shown by diphtheria toxin-induced near-total beta cell ablation [11] and by forced expression of paired box 4 (PAX4) [12], while delta-to-beta cell transdifferentiation occurs in juvenile mice following beta cell ablation [13]. Successful treatment of hyperglycaemic mice with epidermal growth factor (EGF) and gastrin [14] suggested acinar cells as a possible source of novel beta cells, but recent cell-lineage tracing rejected this hypothesis [15]. An acinar origin of beta cells following regeneration of injured pancreas was also disproved by genetic cell-lineage tracing in mice [16]. Nonetheless, transduction of acinar cells by three pancreatic transcription factors necessary for beta cell development was sufficient to induce direct conversion of acinar to functional beta-like cells [17]. Regeneration models that depend on genetic or surgical manipulation, however, hold limited promise for clinical application. We previously reported the ability of two cytokines, EGF and ciliary neurotrophic factor (CNTF), to induce acinar-to-beta cell transdifferentiation in mice with long-term hyperglycaemia [18]. These effects were mediated by neurogenin 3 (NGN3) expression and depended on signal transducer and activator of transcription 3 (STAT3) activation in the acinar compartment.

In the present study, we elaborate on the effects of this combined cytokine treatment in mice with acute chemical beta cell toxicity. We show that $\mathrm{EGF}+\mathrm{CNTF}$ reinstates a functional beta cell mass through rescue of pre-existing beta cells combined with a marginal acino-insular transdifferentiation accompanied by $\mathrm{Ngn} 3$ activation.

\section{Methods}

All mouse experiments were performed according to our institutional ethics committee for animal experiments (project number 10-274-12), following the national guidelines and regulations. All mice strains have been described previously $[1,6,16,19-22]: \mathrm{Rip}^{\mathrm{CreERT}} \mathrm{R} 26^{\mathrm{LacZ}}, H_{n f 1} b^{\mathrm{CreERT}} \mathrm{R} 26^{\mathrm{LacZ}}$,

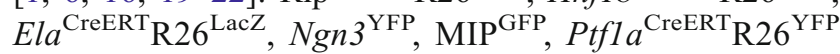
and Stat $^{\mathrm{F} / \mathrm{F}}$. Commercial C57B1/6J mice were purchased from Jackson Laboratory (Bar Harbor, ME, USA). Mice used were males aged 10-12 weeks. Animals were group housed and received cage enrichment.

Mice were injected with the beta cell toxin alloxan (ALX) or vehicle (normoglycaemic [NG]) followed 1 day later by

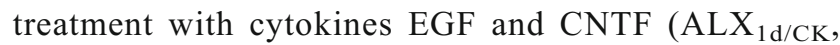
$\left.\mathrm{NG}_{1 \mathrm{~d} / \mathrm{CK}}\right)$ or vehicle $\left(\mathrm{ALX}_{1 \mathrm{~d} / \mathrm{CTR}}, \mathrm{NG}_{1 \mathrm{~d} / \mathrm{CTR}}\right)$. The effect of toxin and cytokines was evaluated by measurement of glycaemia, body weight, insulin in pancreas and serum and abundance of transcripts coding for exocrine and endocrine (progenitor) cell markers. Analysis of the number of reporter ${ }^{+}$ cells from digested pancreas of $N g n 3^{\mathrm{YFP}}$ mice was by flow cytometry. Lineage tracing of beta and acinar cells involved tamoxifen (TAM) exposure and wash out, immunohistochemistry and immunocytochemistry.

Plasma insulin concentration was determined with the Mouse Linco Insulin ELISA kit (Merck Millipore, Darmstadt, Germany). Total pancreas insulin content was determined using a mouse insulin radioimmunoassay kit (Linco Research, St Charles, Missouri, USA).

Insulin pellets (LinShin, Toronto, ON, Canada) were implanted subcutaneously under the mid dorsal skin at a dosage of two pellets for the first $20 \mathrm{~g}$ body weight and one pellet for each additional $5 \mathrm{~g}$ body weight (according to the manufacturer's instructions).

Antibodies used included guinea pig polyclonal antiinsulin (gift from C. Van Schravendijk, Vrije Universiteit Brussel, Brussels, Belgium); rabbit polyclonal anti-NGN3 [23], rabbit polyclonal anti-pancreatic and duodenal homeobox 1 (PDX1) [24]; rabbit polyclonal anti-Ki67 (Novocastra, Newcastle upon Tyne, UK) and anti-amylase (AMY) (SigmaAldrich, Bornem, Belgium), rat polyclonal anti-keratin 19 (Troma-III, Hybridoma Bank, University of Iowa, Iowa City, 
IA, USA), goat polyclonal anti-p48 (C.V. Wright, Vanderbilt, University, Nashville, TN, USA) and goat polyclonal antigreen fluorescent protein (GFP) (Abcam, Cambridge, UK). All antibodies were validated in previous studies.

All methods were performed as described previously [25], with details in the electronic supplementary material (ESM) Methods.

Beta cell mass, number and death analysis Morphometry of the insulin area and determination of the beta cell fraction were performed by sectioning and analysing $2 \%$ of the total pancreas. Beta cell death was analysed using the TUNEL assay (in situ cell death detection kit, TMR Red; Roche, Mannheim Germany) according to the manufacturer's recommendations. Actively cycling beta cells were detected by immune staining for Ki67 and insulin. Counting of $\mathrm{TUNEL}^{+}, \mathrm{GFP}^{+}$and $\mathrm{Ki}^{+} 7^{+}$beta cells was performed by serial sectioning of the entire pancreas followed by staining and counting every 30 th section. A minimum of 4000 insulin $^{+}$ cells were counted per pancreas.

Data analysis All values are shown as mean \pm SEM from three or more independent experiments and considered significant if $p<0.05$. All data were statistically analysed using either unpaired Student's $t$ test, one-way ANOVA or a linear mixed effects model. The results have been substantiated in two different laboratories (Vrije Universiteit Brussel and University of California San Francisco) but performed under similar conditions. Animals were randomly assigned to control or treatment groups. Analyses were performed on all samples and animal identification was verified post acquisition. No animals were excluded from the study based on experimental outcome.

\section{Results}

EGF and CNTF together ameliorate glycaemia in acute diabetic mice A combination of the cytokines EGF and IL6-receptor ligands leukaemia inhibitory factor (LIF) or CNTF is capable of reprogramming acinar cells into insulinproducing beta-like cells in vitro [18] and in vivo [25] via temporal re-expression of the pro-endocrine basic helix-loophelix (bHLH) transcription factor NGN3 [26]. In the present study, the effects of EGF and CNTF were tested in acute diabetic mice (ESM Methods). Hyperglycaemia was provoked by i.v. injection of a single dose of the beta cell toxin ALX [27].

Compared with normoglycaemic mice, ALX-treated mice displayed a sharp and irreversible increase in their blood glucose levels. Cytokine or vehicle was applied through a mini-osmotic pump implanted in the peritoneum $24 \mathrm{~h}$ after ALX injection and releasing the factors at a constant flux rate over a 7 day period (Fig. 1a). The effect of the growth factors was also evaluated in
$\mathrm{NG}_{1 \mathrm{~d} / \mathrm{CK}}$ mice. No significant difference in blood sugar levels was observed between $\mathrm{NG}_{1 \mathrm{~d} / \mathrm{CTR}}$ and $\mathrm{NG}_{1 \mathrm{~d} / \mathrm{CK}}$ mice. However, $\mathrm{ALX}_{1 \mathrm{~d} / \mathrm{CTR}}$ and $\mathrm{ALX}_{1 \mathrm{~d} / \mathrm{CK}}$ mice significantly differed in glycaemia ( $29.7 \pm 1.7$ vs $18.4 \pm 4.0 \mathrm{mmol} / \mathrm{l} ; p<0.01)$ (Fig. 1b). Retrospectively, the $\mathrm{ALX}_{1 \mathrm{~d} / \mathrm{CK}}$ group of 35 mice was subdivided into 24 animals that responded to the treatment $\left(\mathrm{ALX}_{1 \mathrm{~d} / \mathrm{CK}}{ }^{\text {resp }}\right)$ (68.6 $\pm 4.6 \%$ of all $\mathrm{ALX}_{1 \mathrm{~d} / \mathrm{CK}}$ mice) and were indistinguishable from NG mice $(p>0.05)$ and 11 unresponsive $\left(\operatorname{ALX}_{1 \mathrm{~d} / \mathrm{CK}}{ }^{\text {unresp }}\right)$ animals that remained hyperglycaemic $\left(p>0.05\right.$ vs $\left.\operatorname{ALX}_{1 \mathrm{~d} / \mathrm{CTR}}\right)$ (Fig. 1b). Body weight in the NG animals remained stable while ALX injection caused $10 \pm 1 \%$ weight loss $\left(\operatorname{ALX}_{1 \mathrm{~d} / \mathrm{CTR}}\right)$. Cytokine-treated mice lost an additional $5 \pm 2 \%$ of weight $\left(\mathrm{ALX}_{1 \mathrm{~d} / \mathrm{CK}}\right)$, concordant with previous reports of CNTF action $[28,29]$ although we did not observe such a negative effect of $\mathrm{CNTF}$ on body weight in $\mathrm{NG}_{1 \mathrm{~d} / \mathrm{CK}}$ mice. The apparent difference between ALX-treated mice is not statistically significant (Fig. 1c). In animals followed for up to 35 days beyond the 7 day cytokine-release period, glycaemia in the responsive mice remained normal and that in the unresponsive ones high (Fig. 1d). Both total pancreas insulin content and serum insulin levels in $\mathrm{ALX}_{1 \mathrm{~d} / \mathrm{CK}}$ mice reached $50 \%$ of the values detected in $\mathrm{NG}_{1 / / C T R}$ mice (Fig. 1e, f) (ESM Methods). Thus, the combination of CNTF and EGF is capable of reversing ALX-induced hyperglycaemia in mice.

EGF+CNTF activates $\mathbf{N g n} \mathbf{3}$ gene expression To dissect the mechanism behind the growth factor-induced normalisation of glycaemia, the mRNA expression of key regulator proteins in pancreas formation and function was compared in cytokinetreated and control mice at day 7. The transcript level of $\mathrm{Ngn} 3$ (also known as Neurog3) was markedly increased in the $\mathrm{ALX}_{1 \mathrm{~d} / \mathrm{CK}}$ but not in $\mathrm{ALX}_{1 \mathrm{~d} / \mathrm{CTR}}$ mice (Fig. 2). A similar increase was observed for $P d x 1$, Ins 1 and Ins 2 expression, while that of some acinar- (Amy) or duct-specific (Sox9 and Hnflb) genes did not differ significantly. All primer sequences are listed in ESM Table 1.

As the amount of NGN3-encoding transcripts increased, we analysed yellow fluorescent protein (YFP) reporter-expressing cells from dissociated pancreases of $N g n 3^{\mathrm{YFP}}$ mice [19] by flow cytometry, 7 days following the different experimental treatments under study (Fig. 3a) (ESM Methods). Hardly any $\mathrm{YFP}^{+}$cells were detected in $\mathrm{NG}_{1 \mathrm{~d} / \mathrm{CTR}}$ or $\mathrm{ALX}_{1 \mathrm{~d} / \mathrm{CTR}}$ mice $\left(<200 \mathrm{YFP}^{+}\right.$events per pancreas). However, $2604 \pm 194$ $\mathrm{YFP}^{+}$cells were isolated from the pancreas of $\mathrm{ALX}_{1 \mathrm{~d} / \mathrm{CK}}$ nonresponder mice, significantly more than from the pancreas of $\operatorname{ALX}_{1 \mathrm{~d} / \mathrm{CK}}$ responder mice $(n=25 ; p<0.05)$. The isolated cells were small, YFP-immunoreactive and insulin ${ }^{-}$(Fig. 3b). Single $\mathrm{YFP}^{+}$cells were also detected in situ, dispersed throughout the pancreatic tissue (Fig. 3c). They were mainly located in the acinar compartment but on a few occasions were also near insulin $^{+}$cells at the border of islets. On the pancreatic sections, $24.7 \pm 5.1 \%$ of the $\mathrm{YFP}^{+}$cells still stained positive for endogenous NGN3 protein. More than $80 \%$ of the $\mathrm{YFP}^{+}$cells co- 
Fig. 1 Cytokine treatment of acute diabetic mice can reverse hyperglycaemia. (a) Scheme of the experimental design. For details, see the Results section. (b) Blood glucose levels in $\mathrm{NG}_{1 \mathrm{~d} / \mathrm{CTR}}$ and $\mathrm{NG}_{1 \mathrm{~d} / \mathrm{CK}}$ mice $(n=15$ each) and in $\mathrm{ALX}_{1 \mathrm{~d} / \mathrm{CTR}}$ and $\mathrm{ALX}_{1 \mathrm{~d} / \mathrm{CK}}$ mice $\left(n=35\right.$ each). $\operatorname{ALX}_{1 \mathrm{~d} / \mathrm{CK}}$ mice were split into $\mathrm{ALX}_{1 \mathrm{~d} / \mathrm{CK}}$ resp (responsive) and $\mathrm{ALX}_{1 \mathrm{~d} / \mathrm{CK}}$ unresp (unresponsive) mice. (c) The body weight of mice shown in panel (b). (d) 35 days follow-up of glycaemia ( $n=6$ each). (e) Total pancreas insulin content ( $n=6$ each). (f) Serum insulin levels ( $n=6$ each). All data were statistically analysed using a linear mixed effects model (b-d) or a one-way ANOVA (e, f; $* * p<0.01$ compared with $\mathrm{NG}_{1 \mathrm{~d} / \text { CTR mice) }}$

Fig. 2 Pro-endocrine gene expression is activated in $\mathrm{ALX}_{1 \mathrm{~d} / \mathrm{CK}}$ mice. The abundance of transcripts encoding NGN3 (normalised to duodenal Ngn3 expression), insulin 1 (INS1) and 2 (INS2), PDX1, p48, AMY, SRY (sex determining region $\mathrm{Y}$ )-box 9 (SOX9) and HNF1 homeobox B (HNF1B) in $\mathrm{ALX}_{1 \mathrm{~d} / \mathrm{CK}}$ compared with ALX $_{1 \mathrm{~d} / \mathrm{CTR}}$ mice. All data were statistically analysed using the Student's $t$ test a

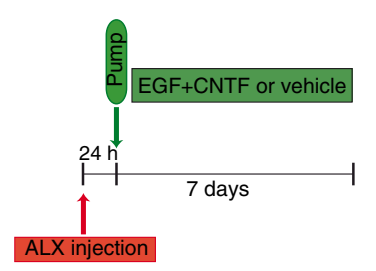

C

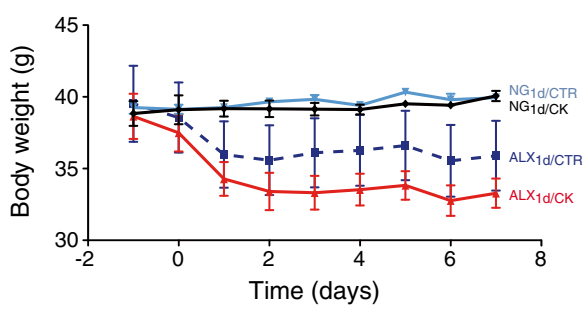

b

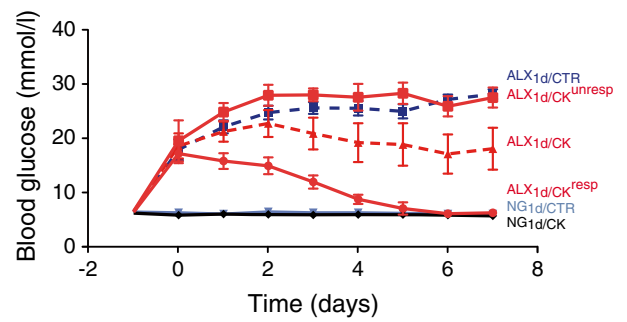

d

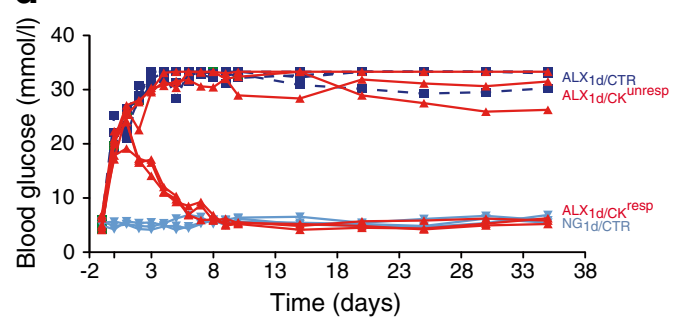

e

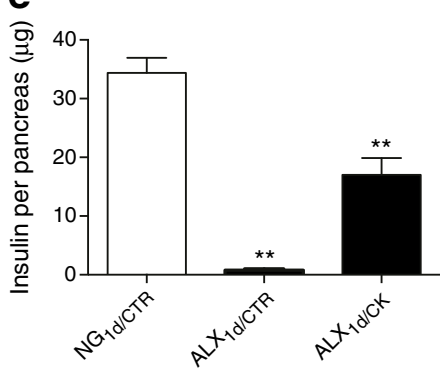

f

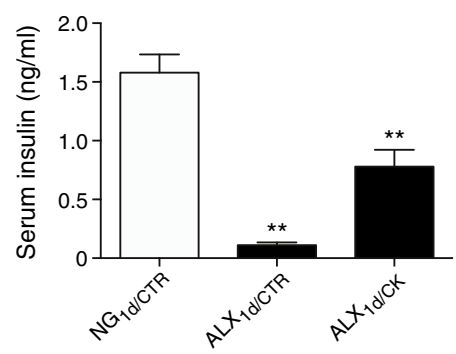

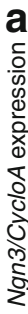
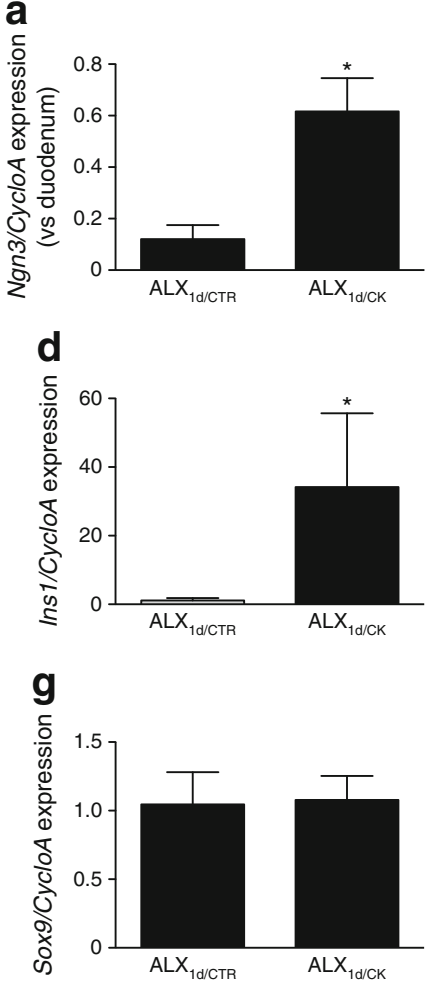
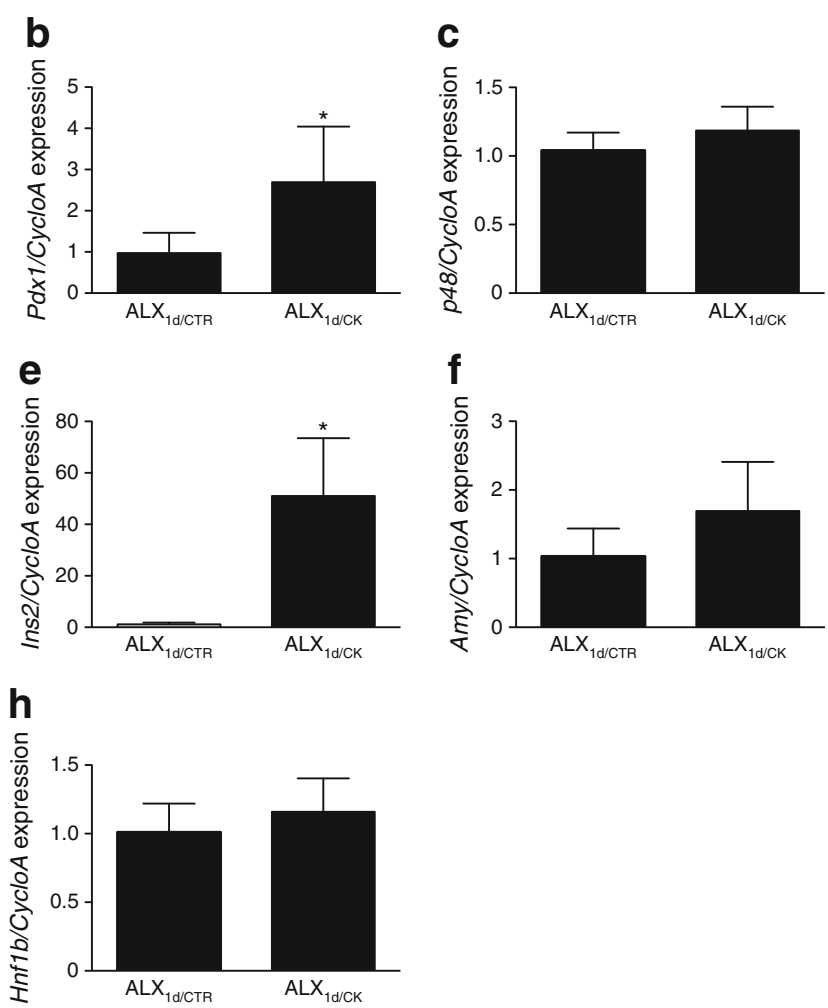
expressed acinar cell-specific markers and approximately $7 \%$ expressed beta cell markers (insulin and PDX1), while none was found in the ductal compartment (cytokeratin $19^{+}$) (Fig. 3c, d) (ESM Methods). Concordant with the data on isolated $\mathrm{YFP}^{+}$cells, the highest number of $\mathrm{YFP}^{+}$cells was detected in situ in the tissue of the $\mathrm{ALX}_{1 \mathrm{~d} / \mathrm{CK}}$ mice $\left(7 \pm 2 \mathrm{YFP}^{+}\right.$cells per $10^{4}$ cells) (Fig. 3e). In $\mathrm{ALX}_{1 \mathrm{~d} / \mathrm{CK}}$ mice only, $\mathrm{NGN3}^{+}$cells could be readily detected in acinar cells, defined by their coexpression of p48 (Fig. 3f). These results indicate that EGF+CNTF induced NGN3 expression predominantly in acinar cells of ALX mice.

EGF + CNTF protects beta cells against toxin-induced destruction To disclose the origin of the insulin ${ }^{+}$cells that appeared following cytokine treatment of $\mathrm{ALX}_{1 \mathrm{~d}}$ mice, cellspecific lineage tracing was performed. Beta cells were labelled by injecting Rip ${ }^{\text {CreERT }}$ R2 $6{ }^{\text {LacZ }}$ mice with TAM 33 days prior to ALX treatment. A washout period of 24 days ensured clearance of the drug. At the end of the washout period, ALX was injected i.v. to render the mice hyperglycaemic and $24 \mathrm{~h}$ later the pump with either vehicle $\left(\mathrm{ALX}_{1 \mathrm{~d} / \mathrm{CTR}}\right)$ or $\mathrm{CK}$ $\left(\right.$ ALX $\left._{1 \mathrm{~d} / \mathrm{CK}}\right)$ was implanted (Fig. 4a). This resulted in $81 \pm 2 \%$ and $85 \pm 2 \%$ of insulin ${ }^{+}$cells reacting with $\mathrm{Xgal}^{+}$ and thus expressing the reporter gene, reflecting the recombination efficiency in control $\mathrm{NG}_{1 \mathrm{~d} / \text { CTR }}$ and $\mathrm{ALX}_{1 \mathrm{~d} / \text { CTR }}$ mice, respectively (Fig. 4b, lower left). The percentage of labelled beta cells decreased to $66 \pm 4 \%$ in $\operatorname{ALX}_{1 \mathrm{~d} / \mathrm{CK}}$ mice $(n=15$, for each individual group; $p<0.01$ ), suggesting approximately $15 \%$ contribution of non-beta cells to the beta cell pool after cytokine treatment. Remarkably, compared with the $2.1 \pm 0.3 \%$ beta cells in the pancreas of $\mathrm{NG}_{1 \mathrm{~d} / \mathrm{CTR}}$ mice, more than $30 \%$ of the insulin ${ }^{+}$cell mass was protected in $\mathrm{ALX}_{1 \mathrm{~d} / \mathrm{CK}}$ mice $(0.6 \pm 0.1 \%)$ but not in $\operatorname{ALX}_{1 \mathrm{~d} / \mathrm{CTR}}$ mice $(0.05 \pm 0.01 \%)$ (Fig. 4b, lower right) $\left(n=15 ; p<0.01\right.$ for $\mathrm{NG}_{1 \mathrm{~d} / \mathrm{CTR}} \mathrm{vs}$ $\operatorname{ALX}_{1 \mathrm{~d} / \mathrm{CK}} ; p<0.05$ for $\operatorname{ALX}_{1 \mathrm{~d} / \mathrm{CTR}}$ vs $\left.\mathrm{ALX}_{1 \mathrm{~d} / \mathrm{CK}}\right)$.

To define the non-beta cell pool that gave rise to beta cells in $\mathrm{ALX}_{1 \mathrm{~d} / \mathrm{CK}}$ mice, pre-existing acinar cells were marked in Ela ${ }^{\text {CreERT }}$ R26 ${ }^{\text {LacZ }}$ mice as in Fig. 4a. In ALX $_{1 \mathrm{~d} / \mathrm{CTR}}$ mice, no $\mathrm{Xgal}^{+}$beta cells were found, whereas in $\mathrm{ALX}_{1 \mathrm{~d} / \mathrm{CK}}{ }^{\text {unresp }}$ mice $2.3 \pm 0.1 \%$ and in $\mathrm{ALX}_{1 \mathrm{~d} / \mathrm{CK}}{ }^{\text {resp }}$ mice $1.6 \pm 0.2 \%$ of the insu$\operatorname{lin}^{+}$cells reacted with Xgal $(n=20$, for each individual group; $p<0.01$ for $\mathrm{ALX}_{1 \mathrm{~d} / \mathrm{CTR}}$ vs $\mathrm{ALX}_{1 \mathrm{~d} / \mathrm{CK}}{ }^{\text {resp }}$ and $\mathrm{ALX}_{1 \mathrm{~d} / \mathrm{CK}}{ }^{\text {unresp }}$ ) (Fig. 4c, lower left). Taking the 30\% recombination efficiency into account (this is the percentage of $\mathrm{AMY}^{+}$cells that were $\mathrm{Xgal}^{+}$[Fig. 4c, lower right]), these data indicate that approximately $6 \%$ of new beta cells converted from acinar cells. In $H n f 1 b^{\text {CreERT }}$ R2 $6^{\text {LacZ }}$ mice that allow tracing of duct-derived cells, the fraction of reporter-expressing insulin ${ }^{+}$cells was $0.7 \pm 0.4 \%$ in $\mathrm{NG}_{1 \mathrm{~d} / \mathrm{CTR}}, 0.8 \pm 0.5 \%$ in $\mathrm{ALX}_{1 \mathrm{~d} / \mathrm{CTR}}$ and $0.9 \pm 0.6 \%$ in $\mathrm{ALX}_{1 \mathrm{~d} / \mathrm{CK}}$ mice $(n=6 ; p>0.05)$ while the recombination efficiency in these mice was approximately $20 \%$ (not shown). Because of the lack of statistical significance when comparing the fraction of reporter-expressing beta cells between the different experimental conditions, no conclusions about the contribution of duct cells to new beta cells can be drawn based on these data.

Beta cell proliferation did not significantly differ between the experimental conditions (Fig. 4d), suggesting that cytokine treatment did not stimulate beta cell proliferation but normalised glycaemia by protecting the residual beta cells. To further evaluate the effect of cytokine on beta cell death, TUNEL assays were performed on ALX $_{1 \mathrm{~d} / \mathrm{CTR}}$ and $\mathrm{ALX}_{1 \mathrm{~d} / \mathrm{CK}}$ mice, $18 \mathrm{~h}$ after implantation of the osmotic pump. All islets of $\mathrm{ALX}_{1 \mathrm{~d} / \mathrm{CTR}}$ mice showed numerous $\mathrm{TUNEL}^{+}$insulin $^{+}$cells, whereas in $\mathrm{ALX}_{1 \mathrm{~d} / \mathrm{CK}}$ mice numerous islets showed little or no TUNEL positivity (ESM Fig. 1a, b).

Using transgenic mice that express the reporter GFP under control of the mouse insulin promoter (MIP ${ }^{\mathrm{GFP}}$ ) [20], we evaluated the presence of de-granulated $\mathrm{GFP}^{+}$insulin ${ }^{-}$cells. Almost all $\mathrm{GFP}^{+}$cells co-expressed insulin at $18 \mathrm{~h}$ after pump implantation in $\mathrm{ALX}_{1 \mathrm{~d} / \mathrm{CTR}}$ as well as in $\mathrm{ALX}_{1 \mathrm{~d} / \mathrm{CK}}$ mice (ESM Fig. 1a-c), arguing against an important role for beta cell de-differentiation in this process.

Thus, treatment with EGF $+\mathrm{CNTF}$ immediately after exposure to ALX is associated with an increased expression of NGN3 in acinar cells, yet only limited acinar-to-beta cell lineage conversion. As beta cells do not show increased proliferation under these experimental conditions and as the number of apoptotic beta cells was significantly decreased in EGF+ CNTF-treated mice, the beneficial effects of these cytokines on beta cell mass are primarily mediated by a protection against acute ALX-induced destruction of beta cells.

Beta cell rescue by EGF + CNTF depends on glycaemia rather than on STAT3-induced NGN3 expression in acinar cells When blood glucose levels were artificially controlled by implantation of insulin pellets (LinBit) on the day of ALX injection, the number of insulin ${ }^{+}$beta cells detected in $\mathrm{ALX}_{1 \mathrm{~d} / \mathrm{CK}}$ mice was strongly reduced $(0.10 \pm 0.03 \%$ in $\mathrm{ALX}_{1 \mathrm{~d} / \mathrm{CK}}{ }^{\mathrm{LinBit}}$ vs $0.90 \pm 0.06 \%$ in $\mathrm{ALX}_{1 \mathrm{~d} / \mathrm{CK}}$ mice; $n=6$; $p<0.001$ ) (Fig. 5a). ALX $_{1 \mathrm{~d} / \mathrm{CK}^{\text {LinBit }}}$ mice also contain lower levels of pancreatic Ngn3 mRNA compared with $\mathrm{ALX}_{1 \mathrm{~d} / \mathrm{CK}}$ mice $(n=6 ; p<0.01)$ (Fig. $5 b)$. In contrast, conditional deletion of Stat 3 from acinar cells (Ptfla ${ }^{\text {CreER }}$ Stat $\left.3^{\text {lox/lox }}\right)$, previously shown to abrogate beta cell neogenesis by EGF+CNTF treatment following chronic hyperglycaemia [25], had no influence on the effect of the cytokines on glycaemia in responsive or unresponsive mice (Fig. 5c). Following cytokine treatment, NGN3 expression was not activated in Ptfla ${ }^{\mathrm{CreER}}{ }_{\text {Stat }}{ }^{\mathrm{F} / \mathrm{F}} \mathrm{Ngn} 3{ }^{\mathrm{YFP}}$ mice with acinar cell-specific Stat3 deletion (Fig. 5d). A total of $1823 \pm 65 \mathrm{YFP}^{+}$cells were isolated from $\mathrm{ALX}_{1 \mathrm{~d} / \mathrm{CK}}{ }^{\text {resp }}$ Stat $3{ }^{\mathrm{WT}}$ mice, $2460 \pm 163$ from $\mathrm{ALX}_{1 \mathrm{~d} / \mathrm{CK}^{\text {unresp }}}{ }^{\text {Stat }} 3^{\mathrm{WT}}$ mice and fewer than 200 $\mathrm{YFP}^{+}$cells were isolated from $\mathrm{ALX}_{1 \mathrm{~d} / \mathrm{CK}}$ mice with Stat3 knockout $\left(\right.$ Stat $\left.3^{\mathrm{KO}}\right)$ mice, similar to the number found in $\mathrm{ALX}_{1 \mathrm{~d} / \mathrm{CTR}}$ animals with wild-type Stat3 $\left(\right.$ Stat $\left.{ }^{\mathrm{WT}}\right)$. 

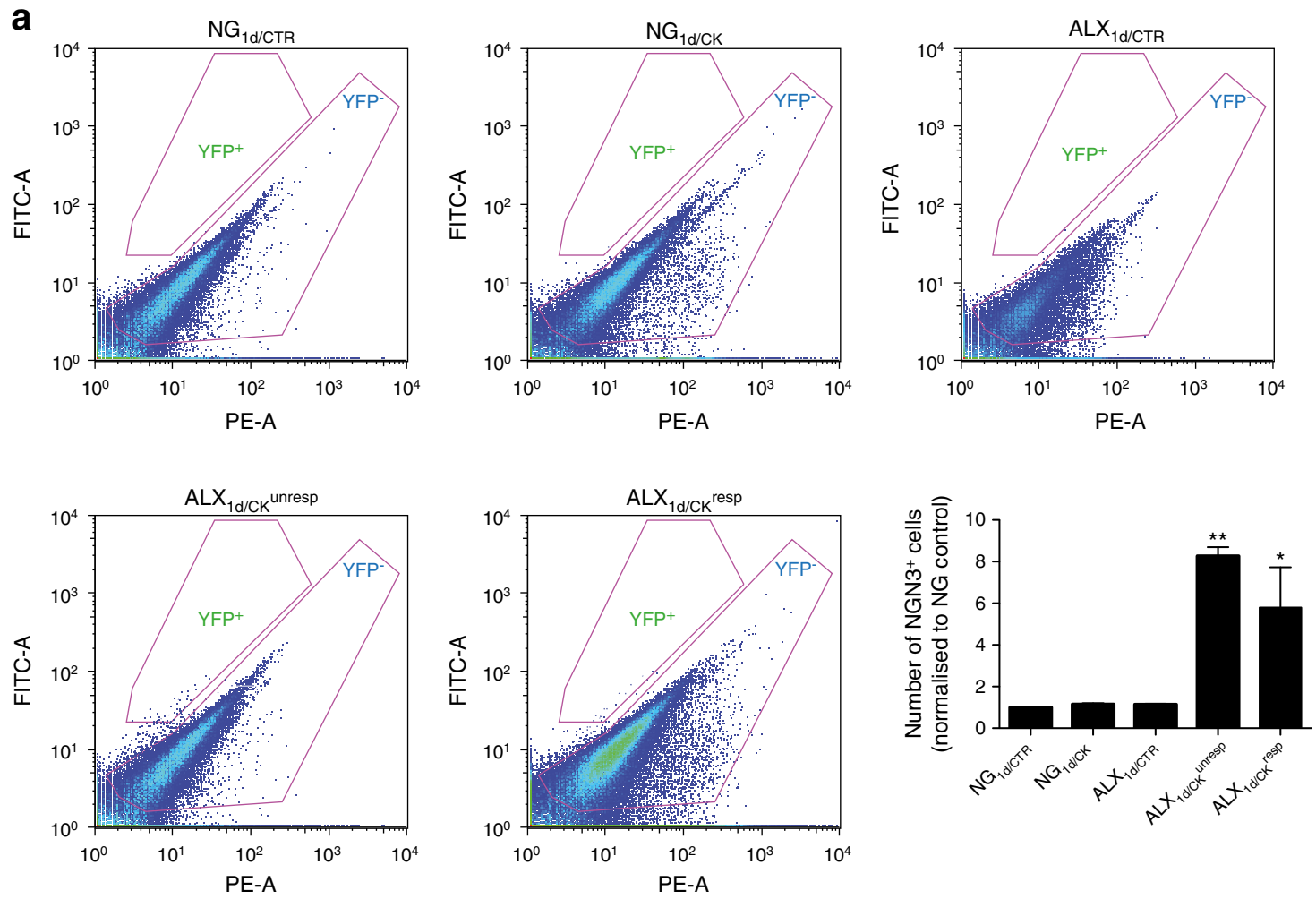

b
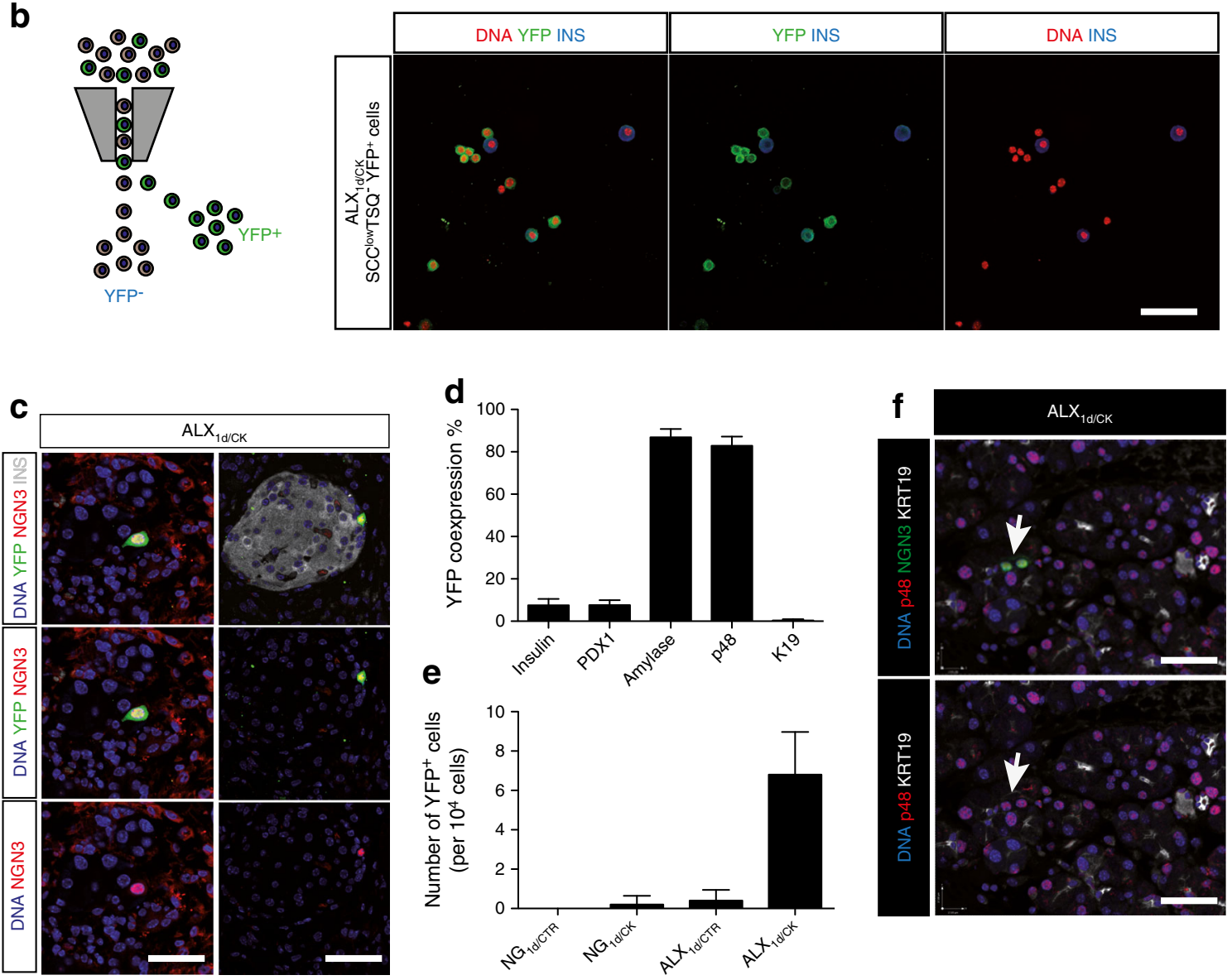
4 Fig. 3 NGN3-expressing cells appear in the pancreas of ALX dd/CK $_{\text {mice. }}$ (a) From pancreas of $\mathrm{Ngn}^{\mathrm{YFP}}$ knock-add-on mice [19], cells that expressed $\mathrm{NGN} 3\left(\mathrm{YFP}^{+} \mathrm{SSC}^{\text {low }} \mathrm{TSQ}^{-}\right.$cells) were analysed by flow cytometry [5, 25] (FITC-A axis is YFP, PE-A is propidium iodide). (b) Immunocytochemistry for insulin and YFP. DNA staining was by SYTO Red. Bar: $30 \mu \mathrm{m}$. (c) Immunohistochemistry for insulin NGN3 and YFP. DNA staining by Hoechst 33342. Scale bars, $15 \mu \mathrm{m}$ left; $30 \mu \mathrm{m}$ right. (d) Quantification of the fraction of $\mathrm{YFP}^{+}$cells that co-express endocrine-, acinar- or duct-cell markers. (e) Quantification of $\mathrm{YFP}^{+}$cells on tissue sections of pancreases collected under the different experimental conditions. (f) Immunohistochemistry for p48, NGN3 and cytokeratin 19 (KRT19). Scale bar, $30 \mu \mathrm{m}$. All data were statistically analysed using one-way ANOVA, ${ }^{*} p<0.05$ and $* * p<0.01$ compared with $\mathrm{NG}_{1 \mathrm{~d} / \mathrm{CTR}}$ mice

EGF + gastrin treatment does not result in activation of NGN3 or acinar cell reprogramming Combined treatment of hyperglycaemic mice with EGF and gastrin has been previously reported to lower blood glucose levels and reinstate normal glycaemic control [14]. Although we were able to confirm these results and demonstrate the effectiveness of $\mathrm{EGF}+$ gastrin $(\mathrm{EG})$ treatment $\left(\mathrm{ALX}_{1 \mathrm{~d} / \mathrm{EG}}\right.$ mice $)$ in reversing the hyperglycaemic state of the mice (ESM Fig. 2a), we were unable to demonstrate any NGN3 activation following this treatment (ESM Fig. 2b). The amount of $\mathrm{YFP}^{+}$cells isolated from digested ALX $_{1 \mathrm{~d} / \mathrm{EG}}$ pancreases is very low $\left(<200 \mathrm{YFP}^{+}\right.$ events per pancreas) and does not differ from ALX $_{1 \mathrm{~d} / \mathrm{CTR}}$ pancreases.

Acinar cell-specific genetic lineage tracing showed that insulin $^{+}$cells expressing reporter were absent in these mice (ESM Fig. 2c), arguing against a potential contribution of acinar cell-derived beta cells in $\mathrm{ALX}_{1 \mathrm{~d} / \mathrm{EG}}$ mice, in contrast to the $\mathrm{ALX}_{1 \mathrm{~d} / \mathrm{CK}}$ model. In addition and in contrast to the data reported by others [15], beta cell-specific genetic labelling was similar in $\mathrm{NG}_{1 \mathrm{~d} / \mathrm{CTR}}$ mice $\left(82 \pm 6 \% \mathrm{Xgal}^{+}\right.$insulin ${ }^{+}$cells) and $\mathrm{ALX}_{1 \mathrm{~d} / \mathrm{EG}}$ mice $\left(78 \pm 5 \% \mathrm{Xgal}^{+}\right.$insulin $^{+}$cells; $n=4$; $p>0.05)$, suggestive of the absence of beta cell neogenesis under these experimental conditions.

\section{Discussion}

Our data demonstrate that the combination of cytokines EGF and CNTF is capable of reversing chemically induced diabetes in mice. Depending on the duration of the diabetic period and the severity of the insult, the mechanism by which the cytokines reinstate normal glycaemic control differs. We previously reported that $\mathrm{EGF}+\mathrm{CNTF}$ reinstates a functional beta cell mass in long-term hyperglycaemic mice through acinar cell reprogramming [25] and presently show that when applied only $24 \mathrm{~h}$ after injury the main mechanism behind the restoration of glycaemic control is rescue of pre-existing beta cells. This observation matches with previous reports identifying pre-existing beta cells as the main source of new beta cells under conditions of moderate damage $[1,2,30]$. When pre-labelled, the majority of the insulin ${ }^{+}$cells in $\mathrm{ALX}_{1 \mathrm{dCK}}$ mice remained reporter positive. Under these experimental conditions, the beta cell cycle was not activated and the number of apoptotic beta cells decreased, strongly suggesting beta cell rescue as the driving force behind normalisation of hyperglycaemia. While the cytokines protect the beta cells from further degeneration and eventual death, a refractory period in terms of beta cell function may be needed, causing hyperglycaemia during the first days of treatment in $\mathrm{ALX}_{1 \mathrm{~d} / \mathrm{CK}}$ mice. Only after sufficient repair can the normal physiological control be reinstated. It is, however, obvious that the same cytokines exert different effects depending on the timing of treatment and the level of tissue damage.

A significant decrease in the number of labelled beta cells was observed in ALX $_{1 \mathrm{~d} / \mathrm{CK}}$ mice when compared with $\mathrm{NG}$ and $\mathrm{ALX}_{\mathrm{CTR}}$ mice, indicating a non-beta cell origin of some of the insulin $^{+}$cells. Transdifferentiated acinar cells were a minor source of new beta cells and even fewer beta cells originated from duct cells. Other non-beta cell types may be reprogrammed to contribute up to $15 \%$ of the new beta cells, although these cell lineages were not traced in the current study. Importantly, normalised glycaemia following acute diabetes remained stable over time, indicating that beta cells with a lasting function were generated by this protective response.

The additional loss in body weight despite the improved glycaemic control in the cytokine-treated mice is most likely the result of a peripheral effect of CNTF, mainly at the level of the fat tissue. An anti-obesity effect has been documented before and appears regulated through activation of leptinlike pathways [28, 31]. These observations have been substantiated by phase II clinical trials using the CNTF analogue axokine, showing a diet-independent loss of body weight [32].

The role of EGF and CNTF in beta cell protection and regeneration is unclear. $E g f$-null mutant mice show no change in the pancreatic phenotype, probably due to redundant expression of ErbB ligands [33]. In adult pancreas, EGF receptor (EGFR) is detected in islet and duct cells, but not in acinar cells [34]. CNTF is expressed by pancreatic beta cells [35], attenuates insulin release and supports beta cell survival through STAT3- suppressor of cytokine signalling 3 (SOCS3) activation [36, 37]. Our data confirm the protective effect of the $\mathrm{CK}$ on residual beta cells through prevention of apoptosis when applied immediately after ALX injection.

Examination of contributions other than from beta cells is, however, needed to fully explain the effect on beta cell mass in this model. Cytokine treatment of mice following short-term hyperglycaemia activated expression of the pro-endocrine embryonic transcription factor NGN3 [38, 39]. The expression of NGN3 increases in the injured pancreas of normoglycaemic adult mice [5] and is low in beta cells of normal adult mice $[25,40]$. As the appearance of NGN3 was restricted to the acinar parenchyma, a cell-autonomous effect of NGN3 in beta 
a
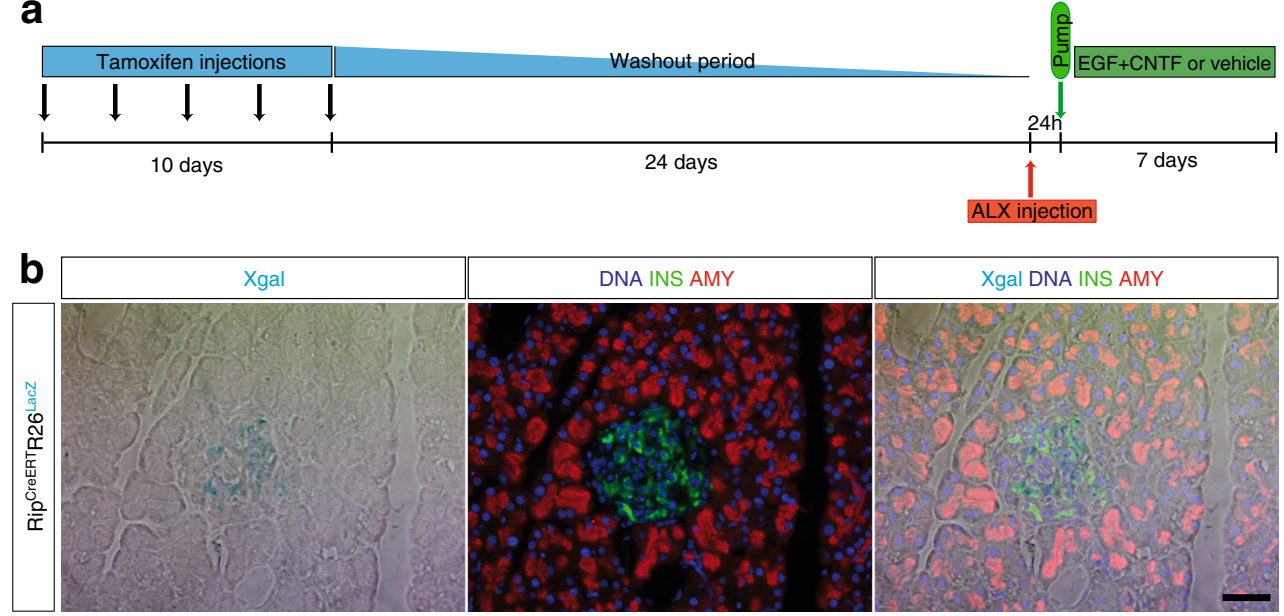

C
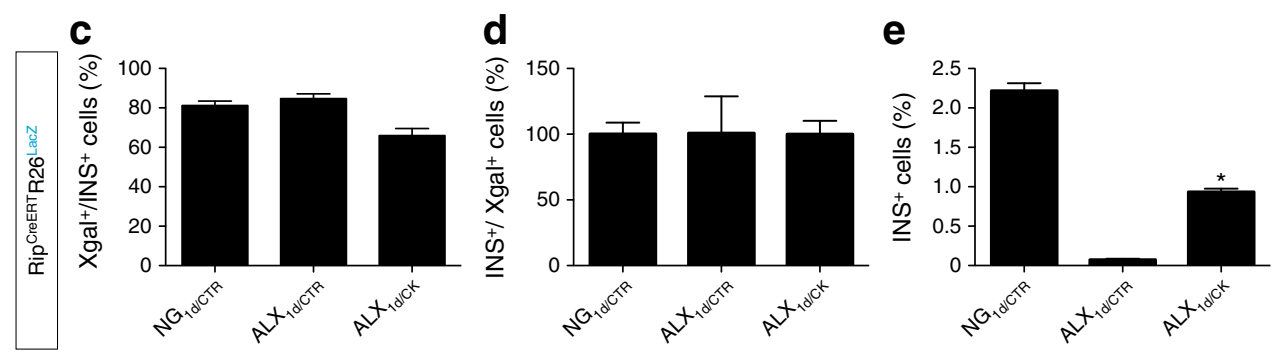

e
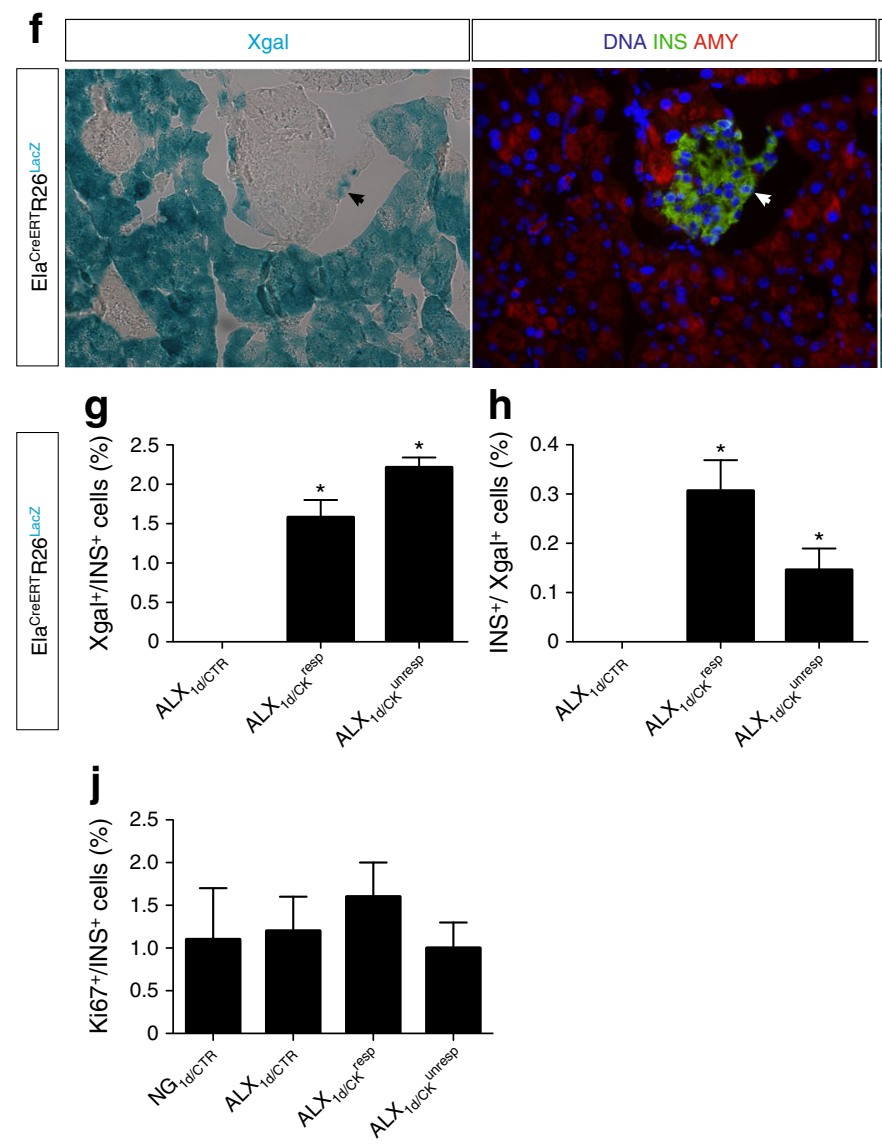
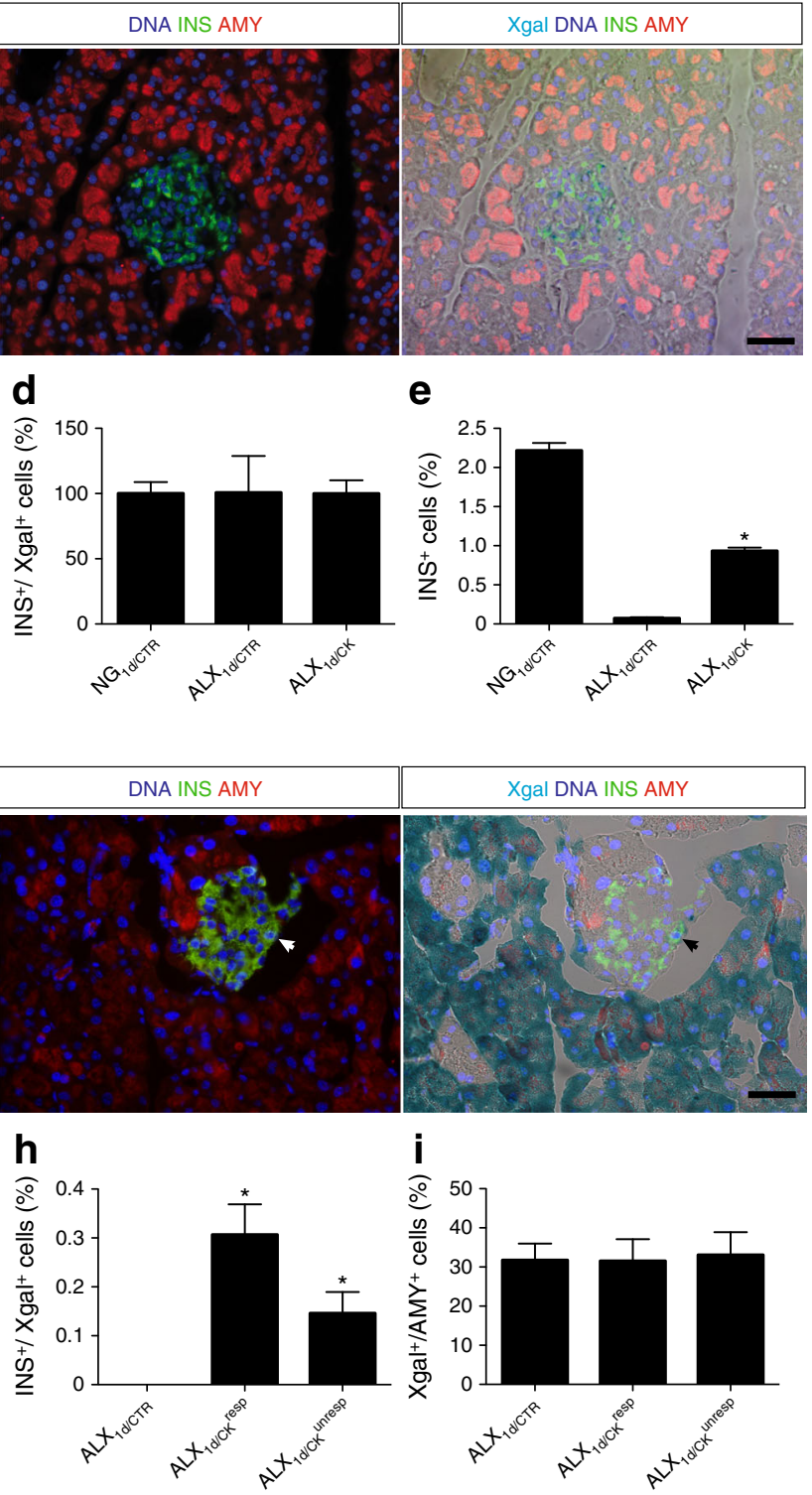

cell recovery is questionable. More likely, acinar cell

contrast to the full acinar-to-beta cell transdifferentiation seen reprogramming is initiated without reaching completion, in 
Fig. 4 Pre-existing beta cells are protected in $\mathrm{ALX}_{1 \mathrm{~d} / \mathrm{CK}}$ mice. (a) Scheme of the experimental design for cell-lineage tracing. Four independent mice were examined for each experimental condition. For details, see the Results section. (b) Beta cell-specific lineage tracing in Rip $^{\text {CreERT }}{ }^{2} 26^{\text {LacZ }}$ ALX $_{1 \mathrm{~d} / \mathrm{CK}}$ mice. Scale bar, $20 \mu \mathrm{m}$. (c) Quantification of Xgal-labelled cells among the beta cells, (d) the specificity of labelling and (e) the percentage of insulin ${ }^{+}$cells in the pancreas. (f) Permanent labelling of the acinar cell lineage in Ela ${ }^{\text {CreERT }} 26^{\text {LacZ }} \mathrm{ALX}_{1 \mathrm{~d} / \mathrm{CK}}$ mice. Scale bar, $20 \mu \mathrm{m}$. (g) Quantification of the percentage of $\mathrm{Xgal}^{+}$and thus acinar cell-derived beta cells, (h) the percentage of $\mathrm{Xgal}^{+}$cells that were insulin $^{+}$and (i) the percentage of acinar cells that were labelled (recombination efficiency). (j) Beta cell proliferation evaluated by Ki67 expression ( $n=10$ for each condition). All data were statistically analysed using one-way ANOVA. ${ }^{*} p<0.05$ compared with $\mathrm{NG}_{1 \mathrm{~d} / \mathrm{CTR}}$ mice $(\mathbf{e})$ or $\operatorname{ALX}_{1 \mathrm{~d} / \mathrm{CTR}}$ mice $(\mathbf{g}, \mathbf{h})$

[25]. The failure to draw sufficient numbers of new beta-like cells from the acinar population is further substantiated by the observation that the highest number of $\mathrm{NGN} 3^{+}$cells was found in animals that were unresponsive to the treatment. We assume that in responsive mice, a faster rescue of beta cells in distress alleviates hyperglycaemia and therefore eliminates the need for new beta-like cells from non-beta populations. The effects of artificial blood glucose control through insulin pellets substantiate this claim: when glycaemia is controlled by exogenous insulin, no apparent beta cell rescue is observed. In addition, exogenous insulin treatment lowered the transcript levels of Ngn3 from that normally observed following cytokine treatment, suggesting that hyperglycaemia may act as a trigger for cytokine-induced Ngn3 activation.

In unresponsive mice, hyperglycaemia persists and more progenitors can be activated under these conditions. As these $\mathrm{NGN}^{+}$cells do not complete transdifferentiation to functional beta-like cells, an important role for the duration of hyperglycaemia on acinar cell priming can be hypothesised. Indeed, cytokine treatment in long-term diabetic animals activates the large number of $\mathrm{NGN}^{+}$cells necessary to drive beta cell differentiation and the mice with most $\mathrm{NGN}^{+}$cells are also most responsive in terms of normalisation of glycaemia [25]. However, the exact mechanism underlying cytokine-
Fig. 5 Beta cell rescue in ALX $_{1 \mathrm{~d} / \mathrm{CK}}$ mice depends on glycaemia but not STAT3mediated NGN3 activation. (a) The number of insulin ${ }^{+}$cells and (b) Ngn 3 transcript levels in $\mathrm{ALX}_{1 \mathrm{~d} / \mathrm{CK}}$ mice without or with exogenous insulin pellets. (c, d) Blood glucose was measured in ALX $_{1 \mathrm{~d} / \mathrm{CK}}^{\text {Ptfla:Stat } 3 \mathrm{WT} \text { or }}$ ALX $_{1 \mathrm{~d} / \mathrm{CK}}{ }^{\text {tfla:Stat } 3 \mathrm{KO}}$ mice $(n=10$ each, five responsive and five unresponsive): (c) $\operatorname{ALX}_{1 \mathrm{~d} / \mathrm{CK}}{ }^{\text {resp; }}$; and (d) $\mathrm{ALX}_{1 \mathrm{~d} / \mathrm{CK}}{ }^{\text {unresp }}$. (e) Quantification of YFP-labelled cells isolated from pancreas of $\mathrm{Ngn} 3^{\mathrm{YFP}}$ reporter mice with acinar cell-specific Stat3 deletion. $n=5$ for each condition. All data were statistically analysed using Student's $t$ test. Dashed line, Stat $^{\mathrm{KO}}$; solid line, Stat 3 WT; ${ }^{*} p<0.05$ compared with "no insulin pellet' $(\mathbf{a}, \mathbf{b})$ or $\mathrm{ALX}_{1 \mathrm{~d} / \mathrm{CTR}}$ mice (e)
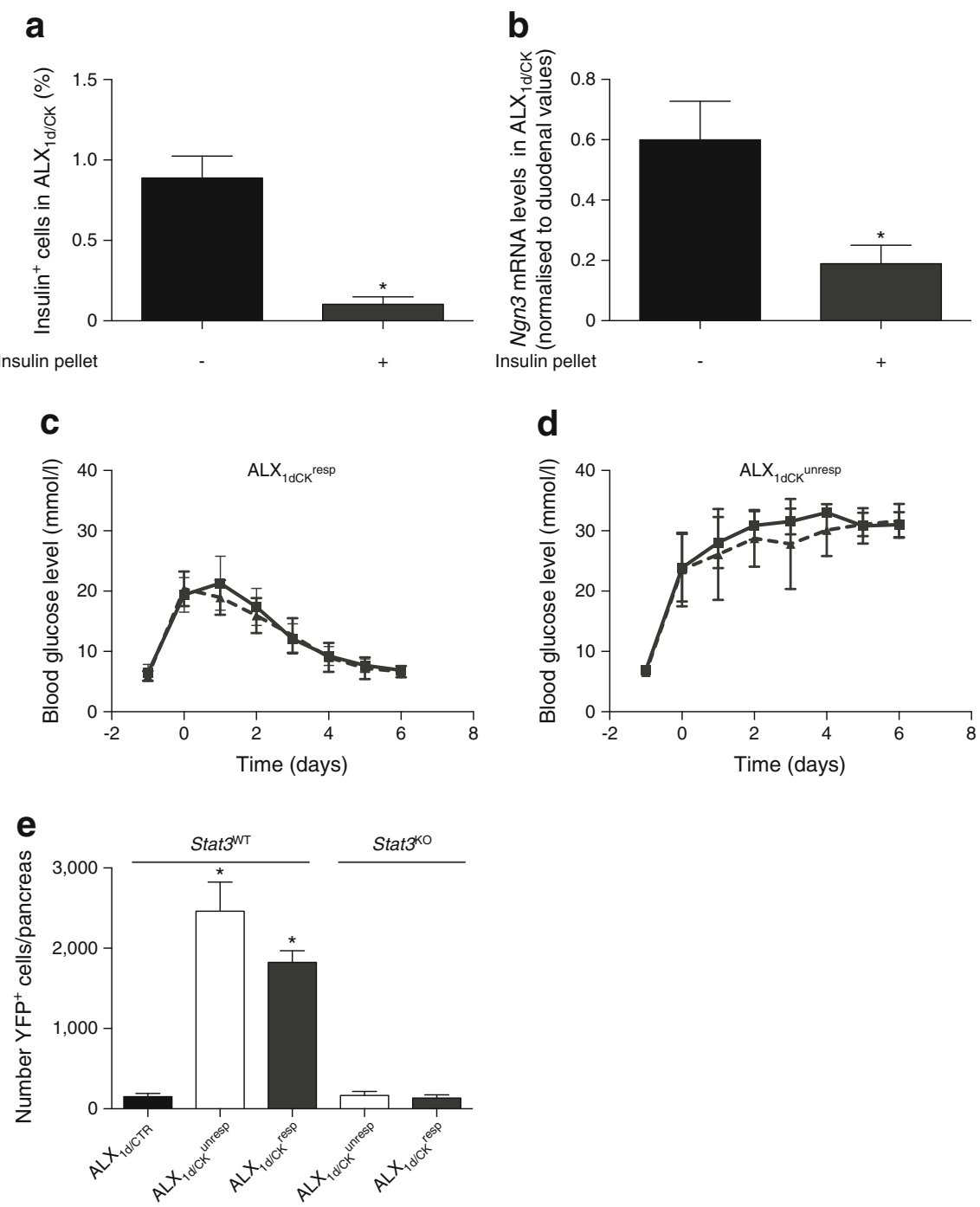
induced Ngn3 activation remains elusive. Based on our previous report on cytokine effects in mice with long-term hyperglycaemia [25], we concluded that STAT3 activation is a critical trigger for cytokine-based Ngn3 activation in the acinar compartment. We now postulate that NGN3 reexpression is not part of cytokine-mediated beta cell rescue, but rather reflects the cytokine effect on acinar cells leading to initiation of acinar-to-beta cell transdifferentiation. The effects observed after deleting Stat 3 specifically in acinar cells further support this idea. On removal of STAT3 prior to the insult, cytokine-treated mice no longer possess the capacity to activate NGN3 expression and increase their number of $\mathrm{NGN}^{+}$ cells. However, Stat 3 deletion from acinar cells does not affect the possibility of $\mathrm{EGF}+\mathrm{CNTF}$ protecting the pre-existing beta cells as the success rate of normalisation of hyperglycaemia in acinar-specific Stat $3^{\mathrm{KO}}$ mice is comparable with that in Stat $3^{\mathrm{WT}}$ mice.

The extent of restoration of the beta cell mass is very similar in cytokine-treated mice with acute and chronic hyperglycaemia, despite the different underlying mechanisms, possibly because of the minimal beta cell mass that is needed for reinstatement of normal glucose control. Once hyperglycaemia is alleviated, the trigger for beta cell regeneration, through either rescue or neogenesis, is removed and the physiological requirement for additional beta cells becomes obsolete.

Insights into the mechanisms of beta cell death and the potential pathways to prevent this are instrumental in devising new strategies to alleviate beta cell stress and death. Taken together, our current and previous studies [25] show how the level of tissue damage determines the choice between protection of residual beta cells and fate re-specification of acinar cells. The present findings may aid in developing new ways to intervene in beta cell death and preserve an existing beta cell mass sufficient to maintain stable glucose control in a setting of recent-onset diabetes.

Acknowledgements Special thanks to V. Laurysens, A. Demarré, E. Quartier and J. De Jonge for technical advice and assistance. We thank Y. Dor, J. Ferrer, C. Wright, G. Gradwohl, M. Hara, D. Stoffers and B. Gao for providing the different transgenic mouse strains used in this study.

Funding LB is an advanced postdoctoral fellow of the JDRF (3-APF2014-183-A-N). Financial support was obtained from the Research Foundation - Flanders (FWO) (HH, LB), the Juvenile Diabetes Research Foundation $(\mathrm{HH})$, the European Foundation for the Study of Diabetes (EFSD) (LB), DON Foundation (www.sdon.nl) (HH), Interuniversity Attraction Pole network VII-P07 DevRepair $(\mathrm{HH})$ and the European Union Sixth (LSHB-CT-2005-512145), Seventh (HEALTH-F5-2009-241883) Framework Program (HH).

Duality of interest The authors declare that there is no duality of interest associated with this manuscript.
Contribution statement All authors were involved in the acquisition, analysis or interpretation of data. ML, SDG, GS, LB and HH were involved in the study concept and design, drafting and critical revision of the manuscript. All authors approved the final version of the manuscript.

$\mathrm{HH}$ is the guarantor of this work and, as such, had full access to all the data in the study and takes responsibility for the integrity of the data and the accuracy of the data analysis.

\section{References}

1. Dor Y, Brown J, Martinez OI, Melton DA (2004) Adult pancreatic beta-cells are formed by self-duplication rather than stem-cell differentiation. Nature 429:41-46

2. Nir T, Melton DA, Dor Y (2007) Recovery from diabetes in mice by beta cell regeneration. J Clin Invest 117:2553-2561

3. Weinberg N, Ouziel-Yahalom L, Knoller S, Efrat S, Dor Y (2007) Lineage tracing evidence for in vitro dedifferentiation but rare proliferation of mouse pancreatic beta-cells. Diabetes 56:1299-1304

4. Talchai C, Xuan S, Lin HV, Sussel L, Accili D (2012) Pancreatic beta cell dedifferentiation as a mechanism of diabetic beta cell failure. Cell 150:1223-1234

5. Xu X, D'Hoker J, Stange G et al (2008) Beta cells can be generated from endogenous progenitors in injured adult mouse pancreas. Cell 132:197-207

6. Solar M, Cardalda C, Houbracken I et al (2009) Pancreatic exocrine duct cells give rise to insulin-producing beta cells during embryogenesis but not after birth. Dev Cell 17:849-860

7. Kopinke D, Brailsford M, Shea JE, Leavitt R, Scaife CL, Murtaugh LC (2011) Lineage tracing reveals the dynamic contribution of Hes $1+$ cells to the developing and adult pancreas. Development 138:431-441

8. Kopinke D, Murtaugh LC (2010) Exocrine-to-endocrine differentiation is detectable only prior to birth in the uninjured mouse pancreas. BMC Dev Biol 10:38

9. Furuyama K, Kawaguchi Y, Akiyama H et al (2011) Continuous cell supply from a Sox9-expressing progenitor zone in adult liver, exocrine pancreas and intestine. Nat Genet 43:34-41

10. Kopp JL, Dubois CL, Schaffer AE et al (2011) Sox9+ ductal cells are multipotent progenitors throughout development but do not produce new endocrine cells in the normal or injured adult pancreas. Development 138:653-665

11. Thorel F, Nepote V, Avril I et al (2010) Conversion of adult pancreatic alpha-cells to beta-cells after extreme beta-cell loss. Nature 464:1149-1154

12. Collombat $\mathrm{P}, \mathrm{Xu}$ X, Ravassard P et al (2009) The ectopic expression of Pax 4 in the mouse pancreas converts progenitor cells into alpha and subsequently beta cells. Cell 138:449-462

13. Chera S, Baronnier D, Ghila L et al (2014) Diabetes recovery by age-dependent conversion of pancreatic delta-cells into insulin producers. Nature 514:503-507

14. Rooman I, Bouwens L (2004) Combined gastrin and epidermal growth factor treatment induces islet regeneration and restores normoglycaemia in $\mathrm{C} 57 \mathrm{~B} 16 / \mathrm{J}$ mice treated with alloxan. Diabetologia 47:259-265

15. Song I, Patel O, Himpe E, Muller CJ, Bouwens L (2015) Beta cell mass restoration in alloxan-diabetic mice treated with EGF and gastrin. PLoS One 10:e140148

16. Desai BM, Oliver-Krasinski J, De Leon DD et al (2007) Preexisting pancreatic acinar cells contribute to acinar cell, but not islet beta cell, regeneration. J Clin Invest 117:971-977 
17. Zhou Q, Brown J, Kanarek A, Rajagopal J, Melton DA (2008) In vivo reprogramming of adult pancreatic exocrine cells to betacells. Nature 455:627-632

18. Baeyens L, De Breuck S, Lardon J, Mfopou JK, Rooman I, Bouwens L (2005) In vitro generation of insulin-producing beta cells from adult exocrine pancreatic cells. Diabetologia 48:49-57

19. Mellitzer G, Martin M, Sidhoum-Jenny M et al (2004) Pancreatic islet progenitor cells in neurogenin 3-yellow fluorescent protein knock-add-on mice. Mol Endocrinol 18:2765-2776

20. Kilimnik G, Kim A, Jo J, Miller K, Hara M (2009) Quantification of pancreatic islet distribution in situ in mice. Am J Physiol Endocrinol Metab 297:E1331-1338

21. Pan FC, Bankaitis ED, Boyer D et al (2013) Spatiotemporal patterns of multipotentiality in Ptfla-expressing cells during pancreas organogenesis and injury-induced facultative restoration. Development 140:751-764

22. Welte T, Zhang SS, Wang T et al (2003) STAT3 deletion during hematopoiesis causes Crohn's disease-like pathogenesis and lethality: a critical role of STAT3 in innate immunity. Proc Natl Acad Sci U S A 100:1879-1884

23. Schwitzgebel VM, Scheel DW, Conners JR et al (2000) Expression of neurogenin 3 reveals an islet cell precursor population in the pancreas. Development 127:3533-3542

24. Wright CV, Schnegelsberg P, De Robertis EM (1989) XlHbox 8: a novel Xenopus homeo protein restricted to a narrow band of endoderm. Development 105:787-794

25. Baeyens L, Lemper M, Leuckx G et al (2014) Transient cytokine treatment induces acinar cell reprogramming and regenerates functional beta cell mass in diabetic mice. Nat Biotechnol 32:76-83

26. Baeyens L, Bonne S, German MS, Ravassard P, Heimberg H, Bouwens L (2006) Ngn3 expression during postnatal in vitro beta cell neogenesis induced by the JAK/STAT pathway. Cell Death Differ 13:1892-1899

27. Szkudelski T (2001) The mechanism of alloxan and streptozotocin action in B cells of the rat pancreas. Physiol Res 50:537-546

28. Henderson JT, Seniuk NA, Richardson PM, Gauldie J, Roder JC (1994) Systemic administration of ciliary neurotrophic factor induces cachexia in rodents. J Clin Invest 93:2632-2638

29. Lambert PD, Anderson KD, Sleeman MW et al (2001) Ciliary neurotrophic factor activates leptin-like pathways and reduces body fat, without cachexia or rebound weight gain, even in leptinresistant obesity. Proc Natl Acad Sci U S A 98:4652-4657

30. Teta M, Rankin MM, Long SY, Stein GM, Kushner JA (2007) Growth and regeneration of adult beta cells does not involve specialized progenitors. Dev Cell 12:817-826

31. Gloaguen I, Costa P, Demartis A et al (1997) Ciliary neurotrophic factor corrects obesity and diabetes associated with leptin deficiency and resistance. Proc Natl Acad Sci U S A 94:6456-6461

32. Gura T (2003) Obesity drug pipeline not so fat. Science 299:849 852

33. Miettinen P, Ormio P, Hakonen E, Banerjee M, Otonkoski T (2008) EGF receptor in pancreatic beta-cell mass regulation. Biochem Soc Trans 36:280-285

34. Miettinen PJ, Huotari M, Koivisto T et al (2000) Impaired migration and delayed differentiation of pancreatic islet cells in mice lacking EGF-receptors. Development 127:2617-2627

35. Wadt KA, Larsen CM, Andersen HU, Nielsen K, Karlsen AE, Mandrup-Poulsen T (1998) Ciliary neurotrophic factor potentiates the beta-cell inhibitory effect of IL-1beta in rat pancreatic islets associated with increased nitric oxide synthesis and increased expression of inducible nitric oxide synthase. Diabetes 47:1602-1608

36. Rezende LF, Vieira AS, Negro A, Langone F, Boschero AC (2009) Ciliary neurotrophic factor (CNTF) signals through STAT3-SOCS3 pathway and protects rat pancreatic islets from cytokine-induced apoptosis. Cytokine 46:65-71

37. Rezende LF, Santos GJ, Carneiro EM, Boschero AC (2012) Ciliary neurotrophic factor protects mice against streptozotocin-induced type 1 diabetes through SOCS3: the role of STAT1/STAT3 ratio in beta-cell death. J Biol Chem 287:41628-41639

38. Gradwohl G, Dierich A, LeMeur M, Guillemot F (2000) Neurogenin 3 is required for the development of the four endocrine cell lineages of the pancreas. Proc Natl Acad Sci U S A 97:16071611

39. Apelqvist A, Li H, Sommer L et al (1999) Notch signalling controls pancreatic cell differentiation. Nature 400:877-881

40. Wang S, Jensen JN, Seymour PA et al (2009) Sustained Neurog3 expression in hormone-expressing islet cells is required for endocrine maturation and function. Proc Natl Acad Sci U S A 106:97159720 